\section{Some contributions to English oral interaction from cooperative learning ${ }^{1}$}

Algunas contribuciones a la interacción oral en inglés desde el aprendizaje cooperativo
Jorge Orlando Robayo Guerrero²

https://doi.org/10.22209/rhs.v7n7a02

Recibido: marzo 27 de 2019.

Aceptado: mayo 28 de 2019.

\section{Abstract}

Cooperative learning allows teachers and learners to develop workshops by teams to build knowledge according to the contents proposed in the English classes. This article is the product of qualitative research, which objective was to explore how cooperative learning improves the oral interaction in English of ninth grade students at a private school in Ubaté, Cundinamarca. This study was framed in the Action Research, the instruments to collect data were the teacher's journal, reflections from each workshop and three interviews to sixteen students of the participating grade. Teamwork, cooperative learning and oral expression in English of ninth grade students

1 Artículo de investigación, producto del trabajo de investigación "Oral interaction is best achieved with your classmate: cooperative learning approach to enrich students' learning process" como requisito para optar al título de Magíster en Docencia en Idiomas de la Universidad Pedagógica y Tecnológica de Colombia.

2 Docente Secretaría de Educación de Cundinamarca. Integrante del Grupo de Investigación Enletawa, Universidad Pedagógica y Tecnológica de Colombia. are highlighted in the results. The conclusions point out that cooperation is a social practice among students that stimulates, motivates and improves learning and oral interaction in English.

Keywords: well-disposed behavior; oral English proficiency; work by teams; qualitative research; social practice.

\section{Resumen}

El aprendizaje cooperativo permite no solo a los estudiantes adquirir conocimientos trabajando en equipo, sino también a los maestros desarrollar los contenidos propuestos en las clases de inglés. Este artículo es producto de una investigación cualitativa, cuyo objetivo exploraba cómo el aprendizaje cooperativo mejora la interacción oral en inglés de los estudiantes de noveno grado en un colegio privado de Ubaté, Cundinamarca. Este estudio se enmarcó dentro de la Investigación Acción, utilizando como instrumentos de recopilación de datos: el diario del maestro, las reflexiones de cada taller y tres entrevistas grupales a los dieciséis estudiantes del grado participante. Finalmente, los resultados y las conclusiones muestran que el trabajo en equipo y la cooperación son prácticas sociales entre los estudiantes, lo cual estimula, motiva y mejora el aprendizaje y la interacción oral en inglés.

Palabras claves: buena actitud; hablar en inglés; trabajo en equipo; investigación cualitativa; práctica social. 


\section{Introduction}

T heEnglishteaching-learning process takes into account reading, writing, listening and speaking skills in order for students to be able to develop the English speaking competence, specially, oral interaction. Nevertheless, in our schools, many English teachers have focused the learning process on writing and reading skills, with activities such as filling the gaps on copies, complete blanks, identify vocabulary (verbs, nouns, etc.) among others. It means that the students have learnt English language based on grammar aspects instead of getting involved into working in small groups to foster spoken English.

This research project was based on the conception that English language learning process works better if we are cooperative; it means working together to achieve a determined goal. Related to the students' learning process, the cooperative workshops encouraged not only the English oral interaction, but it made the English learning process a useful experience for ninth graders and made the English classes more enjoyable. Besides, it guided the students to control their own learning, developing habits to increase the English language usage into the classroom context. On the other hand, in terms of the teaching process, this investigative practice generated a support for innovation in pedagogy and education fields.

The investigation was carried out at the private school San Francisco de Asís, in UbatéCundinamarca. The sample for this research was made up of sixteen students, divided into five small groups, to whom five workshops were applied in order to develop their oral interaction and the students' well-disposed behavior, which made possible a better involvement of students in their academic process.

Taking into account these ideas, this paper presents a research study based on the implementation of cooperative learning approach as a pedagogical strategy to improve ninth graders' oral interaction. The investigation was based on asserts about cooperative learning and oral interaction concepts of many authors such as Holt, Chips \& Wallace (1991), Johnson \& Johnson (1989), Kagan (1994), Hamm and Adams (1992), Cohen (1972), Slavin (1995), Cooper (1979), among others. Taking into consideration that the cooperative learning concept was based on recognizing that team members share academic commonalties and recognizing that the student's performance is caused by themselves, we explored the cooperative learning possibility in the teachinglearning process to make the students interact among each other using English language into the classroom.

This research was guided by the question: How to improve oral interaction in ninth graders at "Colegio Cooperativo San Francisco de Asís" from UbatéCundinamarca through the implementation of cooperative learning approach?

\section{Theoretical Framework}

There are many studies from researchers that have published their outcomes about cooperative learning such as Coleman (1961), Slavin (1964), Holt, Chips \& Wallace (1991) who advice that students must work in teams to help each other mastering academic content and improving academic and personal 
performances. A research by McGroarty (1993) shows that group work benefits second language learners in three ways: input, interaction and contextualization of knowledge. Kagan (1994) states that when students work together the positive interdependence that develops, foster social behavior and improve ethics relations. Working together help language development as well because students have the chance to use the language for a variety of purposes. Thus, cooperation is a tool that allow people to interact and to learn in an exploring environment where students are the main characters, by means of a permanent interaction between peers, studentteacher, student-student, and group work.

Johnson \& Johnson (1995) and Brandt \& Ellsworth (1996) spoke about factors for successful cooperative learning: "positive interdependence, individual accountability, faceto-face interactions, social skills, appropriate leadership, communication skills, work reflection", among others. Olsen \& Kagan (quoted by Oxford, 1997 , p. 18), cooperative learning is assumed as a "group learning activity organized, thus, learning is dependent on the socially structured exchange of information between learners in groups and in which each learner is held accountable for his or her own learning and is motivated to increase the learning of others".

From this research experience, cooperative learning goes beyond group work, because students helped and supported among them to complete the tasks, it means, they offered assistance to each other for mutual benefit. When ninth graders worked together, they were more receptive and their interaction was more enthusiastic. Agreeing to this experience, cooperative learning was an approach that permitted students to interact, learn and solve problems.

\section{Methodology}

It was a qualitative research with an action research approach. Firestone (1987) and Mills (2003) define action research as a systematic inquiry, conducted by teachers with a vested interest in the teaching and learning process or environment for the purpose of gathering information about how their particular schools operate, how they teach, and how their students learn. By their part, Parson \& Brown (2002) state that action research allows teacher to study their own classroom, their own instructional methods, their own students, their own assessment; in order to better understand them and be able to improve their quality or effectiveness.

In addition, Kemmis \& McTaggart (2000) support that "action research is used to refer to teacher-initiated classroom investigation which seeks to increase the teacher's understanding of classroom practices" (p. 45). Action research involves investigations in the teacher's own classroom; in that way, the whole research study followed next four phases: planning, action, observation and reflection.

Planning. It is not necessary to depend on a hypothesis; what it needs is to observe carefully what is happening into the classroom to be able to detect what aspect, kind of interaction or behavior can give into a different problem. On this step, the English learning concern that called the attention was to characterize the ninth graders' oral interaction as a consequence of the implementation of cooperative learning.

Action. Theaction plan had to do with cooperative workshops. Five workshops were designed for small groups (teams) of four or three members in order to interact sharing students' speeches 
about the topic that we were studying. Every workshop presented a determined objective. In this stage, the students were committed to the process of the investigation.

Observation. The data was collected through interviews and the teacher's journal. The purpose of it was to establish relations between the students' strengths and weaknesses in their English language use. Based on the observation, the researcher could present the qualitative data collected by means of the research instruments.

Reflection. Every workshop had a critical reflection about the teaching practice, the development of the activities and the students' way to achieve the goal. In addition, it allowed to improve next workshop to be applied in the research process, describing and understanding the educational values that underlie our practices. In this way, some aspects were taken into account such as students' speech, personal relations and work in teams, among others.

\section{Population}

The research study was carried out at "Colegio Cooperativo San Francisco de Asis". It is a private institution located in the rural area of Ubaté - Cundinamarca. Since 1964 to 1974 , the Franciscanos community administered it; later, the student's parents cooperative administered it. Its main characteristic is based on the following values: respect, responsibility, personal grow, honesty and catholic principles. The whole group consisted of 16 students among 13-15 years old. There were seven girls and nine boys, most of them came from the rural areas. The participants of this work were ninth graders since 2015. The whole group participated on workshops, four participants were interviewed, one student per team, and the teacher's diary was written in each session. Next table (Table 1) shows a description of each one of the participants in this research study.

Table 1. Description of each one of the participants.

\begin{tabular}{|c|c|c|c|c|c|c|c|}
\hline Students & Genre & Age & Personality & Hobbies & & & \\
\hline & & & Introvert & Extrovert & Creative & Responsible & \\
\hline Ss. 1 & Male & 13 & & & & & Music, Dance, TV, soccer \\
\hline Ss. 2 & Male & 13 & & & & & Music, draw, soccer, TV \\
\hline Ss. 3 & Female & 13 & & & & & Music, read, volleyball \\
\hline Ss. 4 & Male & 13 & & & & & Music, read, soccer, BMX \\
\hline Ss. 5 & Female & 14 & & & & & Music, TV, basketball \\
\hline Ss. 6 & Female & 13 & & & & & Music, basketball \\
\hline Ss. 7 & Male & 14 & & & & & Music, read, soccer \\
\hline Ss. 8 & Male & 14 & & & & & Music, draw, soccer \\
\hline Ss. 9 & Female & 13 & & & & & Music, read, sing \\
\hline Ss. 10 & Female & 13 & & & & & Music, TV, basketball \\
\hline Ss. 11 & Male & 13 & & & & & Music, read, soccer \\
\hline Ss. 12 & Female & 13 & & & & & Music, TV, make up \\
\hline Ss. 13 & Male & 15 & & & & & Music, TV, soccer \\
\hline Ss. 14 & Male & 13 & & & & & Music, basketball, soccer \\
\hline Ss. 15 & Female & 14 & & & & & Music, read, basketball \\
\hline Ss. 16 & Male & 14 & & & & & Music, draw, soccer \\
\hline
\end{tabular}


For some of them, their conception about English was not a positive one. This perception was showed through their lack of oral interaction. Because of this, they failed some periods and did not reflect any improvement in their English learning process. They were used to get low grades and they conceived the English learning as a complicated issue but not as a way to acquire knowledge, enrich the culture and, consequently, as an opportunity for their future lives.

\section{Research instruments}

With regard to collecting data, I applied permanent observation, which involved three instruments: journal, interview (structured/semistructured) and workshops' reflection. First, the teacher's diary helped to show information about the development of activities during the workshops; it supported to record the students' attitudes and their oral interaction. Concerning to teacher's diary, Porlán \& Martín (2000, p. 26) stated, it "fosters the development of a deeper description of the classroom's dynamics through detailed account on the different events and everyday situations. The same fact to reflect it by writing, favors the development of capacities of observation and categorization of reality, allowing go beyond the simple intuitive perception".

Second, interviews (structured/semistructured) recorded the students' reactions about the development of workshops. According to Calderón-Noguera (2011, p. 13) the interview is a research instrument to collect data, "it is characterized by dialogue between at least two persons. It is a flexible instrument, where the interviewer and interviewee interact building an inter-subjective reality".
According to Casteblanco-Cifuentes (2015, p. 283) the workshop "expresses work and strong achievements in learning, since it is based on learning by doing or experiencing the events where both theory and practice are linked. The workshop is a strategy that allows the activity around a school subject". And she continues, "the workshop is an activity where the students develop new knowledge and confront their skills with the help of the teacher" [translated by the researcher]. Kisnerman (quoted by Casteblanco-Cifuentes, 2015, p. 283), stated that the workshop is "a production unit of knowledge from a concrete reality, to be transferred to that reality to transform". So, workshops' reflections were used as instrument because that collected information along each session helped to support the present investigation.

\section{Pedagogical proposal}

This proposal implied five workshops with a variety of cooperative learning activities to improve the ninth graders English oral interaction. The members of the teams were responsible not just for learning what the teacher was teaching, but also for helping teammates to learn. This aspect created an atmosphere of achievement. Students worked through the assignment until all small group members understood and completed it.

To know the worth of the contribution of this paper, I need to say that it consisted on adapting those steps and procedures all led to improve the English language level for school students, in this case, in order to be applied with ninth graders of "Colegio Cooperativo San Francisco de Asis" from Ubaté-Cundinamarca. I really wanted those ninth graders to interact orally among each other using English language in an 
easy way. Thus, the results with the cooperative approach concerning oral interaction were especially significant.

\section{Data analysis}

The process followed to analyze the data gathered began in reading, re-reading, making triangulation. It means, comparisons and contrasting the information provided by each one of the instruments. Then, I identified and underlined common patterns in each instrument. After that, I wrote down in a separate paper language aspects in which I could include the information found in each instrument. Finally, I named the categories to explain in the data analysis the research study.

According to Firestone (1987, p. 93), data analysis is the process to order, structure and give meaning to the data in order to explain that data collected by the researcher. In this way, the researcher enters into the dialogue with it, questioning and finding new meanings. Taking into account the previous considerations, this analysis was supported through the research instruments which were based on the classroom's sessions. These instruments explored students' experiences during the learning process along this study. Interviews, workshops' reflections and teacher's diary provided with the information to be analyzed and answer to the research question.

\section{Findings}

During the study, the ninth graders of Institución Educativa Colegio Cooperativo San Francisco de Asís, Ubaté-Cundinamarca, had the opportunity to speak with freedom about different themes and issues that they concluded from their real life, experiences and other situations. Once the students completed the required task, each group shared their work orally in front of the other groups. We created a cooperative learning environment and not a competitive one; so, when a member of a group made a possible mistake it was an opportunity for them to reinforce and overcome the issue as a team.

Students increased their vocabulary by means of the development of cooperative environment. Every session concluded with oral presentations. So, it must be said that the development of the speaking skill in this ninth graders group was a challenge, since it was not an easy task to make people speak in a foreign language. Nevertheless, all of that collected information could show the credibility of the gathered data. From the analysis one category and two subcategories were defined (Table 2).

Table z. Category and two subcategories.

\begin{tabular}{|l|l|l|}
\hline \multicolumn{1}{|c|}{ Question } & Category & Sub-categories \\
\hline $\begin{array}{l}\text { How to improve oral interaction in ninth graders at } \\
\text { "Colegio Cooperativo San Francisco de Asís" from Ubaté- } \\
\begin{array}{l}\text { Cundinamarca through the implementation of cooperative } \\
\text { learning approach? }\end{array}\end{array}$ & $\begin{array}{l}\text { - English Oral interaction } \\
\text { is best achieved with the } \\
\text { classmates }\end{array}$ & $\begin{array}{l}\text {-well-disposed behavior } \\
\text {-Oral Proficiency }\end{array}$ \\
\hline
\end{tabular}




\section{Oral interaction is best achieved along with classmates}

This category emerged as a result of the data analysis focused on team group and speaking because students learn best in situationswhere their attention is focused on meaningrather than on language; and students communicateeasier in informal settings and in situations where they can express their emotions and attitudes. The students seemed responsible and committed with the cooperative learning activities that they developed in oral way into their groups. Thanks to that, the students strengthed their oral interaction they felt that the goals had been reached. As Table $\mathbf{3}$ shows, most of the students agreed it is significant to recognize others' voices to grow as integral individuals.

\section{Table 3. Extracts.}

\begin{tabular}{|c|c|c|}
\hline Extracts from workshops & Extracts from Diary & Extracts from interviews \\
\hline $\begin{array}{l}\text { - "the students developed their } \\
\text { cooperative roles inside the team, } \\
\text { one student described the picture, } \\
\text { and another described the TV, } \\
\text { magazine photos and the rest } \\
\text { listened to and corrected if it was } \\
\text { necessary, and so on. Finally, the } \\
\text { students made their presentations in } \\
\text { front of the whole group" (I Workshop } \\
\text { research cycle, pag. 37). } \\
\text { - "some students did not like the } \\
\text { idea of acting, because they dislike } \\
\text { performing for an audience, but } \\
\text { co-workers tried to motivate } \\
\text { among them to achieve the goal" (II } \\
\text { Workshop research cycle, pag. 44). }\end{array}$ & $\begin{array}{l}\text { - "Ellos manifestaron su agrado por el taller, lo } \\
\text { cual nos dio a entender que los estudiantes } \\
\text { les gusta trabajar siempre y cuando haya } \\
\text { algo novedoso para hacer en aras del } \\
\text { aprendizaje, elementos como las imágenes } \\
\text { de la revista, el espacio extramural y trabajar } \\
\text { en equipo ayudan al estudiante a salir de } \\
\text { lo convencional para provocar en ellos } \\
\text { nuevas actitudes frente a sus procesos de } \\
\text { aprendizaje" (Diario 01, pág. 39). } \\
\text { - "Los estudiantes prepararon en equipo } \\
\text { la presentación de sus héroes, las } \\
\text { comparaciones de éstos con los que se } \\
\text { proyectaron en el video beam y, finalmente, } \\
\text { los estudiantes escribieron dos párrafos } \\
\text { acerca de los superhéroes para ser } \\
\text { socializados con todo el grupo" (Diario 02, } \\
\text { pág 46.). }\end{array}$ & $\begin{array}{l}\text { “...si uno no sabe el compañero } \\
\text { le puede aportar mucho a uno, } \\
\text { entonces es como cooperativo, } \\
\text { si uno no sabe le enseña el } \\
\text { compañero y si el compañero } \\
\text { no sabe uno le enseña al } \\
\text { compañero...". (Entrevista 01, } \\
\text { Diana. 26"). } \\
\text {...la solidaridad entre } \\
\text { compañeros, y como de que } \\
\text { a veces he incluso hay más } \\
\text { confianza entre compañeros } \\
\text { que con el profesor". (Entrevista } \\
\text { 01, Diana. } 49 \text { "). }\end{array}$ \\
\hline
\end{tabular}

As I just said before, to reach the oral interaction, the ninth graders established relationships to interact each other in English, not just taking the turn when the teacher gave the instructions. In this way, next table (Table 4) shows that the students could tell something to express him/herself in English. Based on this research experience, oral interaction is one of the main features in the students' English learning process.

Table 4. Extracts.

\begin{tabular}{|c|c|c|}
\hline Extracts from workshops & Extracts from Diary & Extracts from interviews \\
\hline $\begin{array}{l}\text {-"The students solved the problem and } \\
\text { achieved the goal, it means, they had } \\
\text { a good presentation, socializing the } \\
\text { possible solutions to the given problem" } \\
\text { (III Workshop research cycle, pag. 45). } \\
\text {-"The development of this workshop } \\
\text { supported their cooperation and the } \\
\text { teamwork" (III Workshop research cycle, } \\
\text { pag. 42). }\end{array}$ & $\begin{array}{l}\text {-"Los estudiantes se desplazaron en } \\
\text { equipos a los lugares escogidos por ellos } \\
\text { para proceder a hacer sus descripciones" } \\
\text { (Diario 04, pág. 59). } \\
\text {-"Cada equipo tomó fotos para ser puestas } \\
\text { en diapositivas y apoyar sus exposiciones. } \\
\text { Cada grupo fue pasando al frente con sus } \\
\text { descripciones, mientras los otros equipos } \\
\text { restantes, hicieron una pregunta al respecto } \\
\text { del lugar que se estuviera describiendo, } \\
\text { siempre usando frases que incluyeran } \\
\text { preposiciones" (Diario 04, pág. 59). }\end{array}$ & $\begin{array}{l}\text {-Bien porque podemos } \\
\text { intercambiar ideas que } \\
\text { podemos también saber lo } \\
\text { que los demás piensan". } \\
\text { (Entrevista 02, Felipe. } 37 ") \text {. } \\
\text {-Claro, podemos aprender lo } \\
\text { que uno no sabe y también } \\
\text { dar a conocer. (Entrevista } \\
\text { 02, Felipe. } 49^{\prime \prime} \text {.). }\end{array}$ \\
\hline
\end{tabular}


I observed that through cooperative learning workshops, it was possible to make the students work together learning and putting into practice oral interaction; it was confirmed in all activities from the beginning to the end of this investigation. As Table $\mathbf{5}$ shows, the development of those cooperative workshops allowed the students' oral interaction by actions like constructing answers together, making questions, doing presentations, watching short documental and talking about different issues from academic topics and themselves.

Table 5. Extracts.

\begin{tabular}{|c|c|c|}
\hline Extracts from workshops & Extracts from Diary & $\begin{array}{c}\text { Extracts from } \\
\text { interviews }\end{array}$ \\
\hline $\begin{array}{l}\text { - "they participated most often and they had the opportunity to } \\
\text { give their own points of view and make their own conclusions } \\
\text { around the theme we talking about". } \\
\text { - "They also wrote a pair of paragraphs for expressing their } \\
\text { points of view, taking into account some characteristics of } \\
\text { their heroes". (II Workshop research cycle, pag. 47). } \\
\text { - "The students agreed to describe five of those places by } \\
\text { groups, working together, at the same time, but in different } \\
\text { place. Besides, the students had to write three questions } \\
\text { about their places to other teams' presentations. After that, } \\
\text { they answered those questions they made using expressions } \\
\text { with prepositions to both questions and answers. The } \\
\text { students had to write down that information in their } \\
\text { notebooks". } \\
\text { - "the students' performance was too nice, since all of them } \\
\text { were able to work cooperatively on these workshops; this } \\
\text { aspect has allowed to improve the oral interaction and to be } \\
\text { spontaneous". (IV Workshop research cycle, pag.60). } \\
\text { - "They delegated functions in order to look for information, } \\
\text { images, video-shorts; they prepared the oral speech, took } \\
\text { advantage of the feedbacks helping each other; in the } \\
\text { presentation, they assigned turns to be organized and had a } \\
\text { coherent performance. It showed that they felt comfortable } \\
\text { working with cooperative approach". } \\
\text { - "They worked together, each with her/his contributions to the } \\
\text { achieved goal, since they knew they were working together } \\
\text { and the result depended of their interdependence, it means, } \\
\text { the students learnt what the teacher taught and, in this } \\
\text { way, they helped each other to learn as well". (V Workshop } \\
\text { research cycle, pag. 68). }\end{array}$ & $\begin{array}{l}\text { - "Los miembros de los equipos } \\
\text { conversaron acerca de la } \\
\text { caricatura que les gustaba, } \\
\text { se les entregó un afiche de } \\
\text { cuatro héroes de los comics: El } \\
\text { Chapulín Colorado, Superman, } \\
\text { Batman y Volfverin. Se les } \\
\text { preguntó acerca de ellos y lo } \\
\text { que tenían que hacer como } \\
\text { héroes" (Diario 02, pág. 46). } \\
\text { - "Los estudiantes prepararon } \\
\text { sus exposiciones con video } \\
\text { beam, y para fortalecer sus } \\
\text { dinámicas, proyectaron } \\
\text { imágenes y videos de } \\
\text { algunos documentales que } \\
\text { encontraron en internet. } \\
\text { En cada exposición, los } \\
\text { estudiantes se veían seguros } \\
\text { de sí, se organizaron de tal } \\
\text { forma que todos los miembros } \\
\text { del equipo entendían qué iban } \\
\text { a decir y en qué momento. Al } \\
\text { final, el profesor lanzó unas } \\
\text { preguntas respecto del tema } \\
\text { de cada equipo, la respuesta } \\
\text { debía estar pensada en equipo } \\
\text { y preparada para que cualquier } \\
\text { miembro la pudiera contestar". } \\
\text { (Diario 05, pág.67). }\end{array}$ & $\begin{array}{l}\text { - Pienso que es muy } \\
\text { divertido siempre } \\
\text { y cuando haya } \\
\text { personas que te } \\
\text { colaboren y no te } \\
\text { toque a ti hacer todo } \\
\text { el trabajo. (Entrevista } \\
\text { 03, Natalia. 29"). } \\
\text { - Es demasiado útil } \\
\text { trabajos cooperativos } \\
\text { no cuando a uno } \\
\text { le toca hacer } \\
\text { todo es muy útil } \\
\text { porque uno ve a las } \\
\text { demás personas y } \\
\text { tienes diferentes } \\
\text { perspectivas } \\
\text { sobre algún tema. } \\
\text { (Entrevista 03, } \\
\text { Natalia. } 40 \text { "). }\end{array}$ \\
\hline
\end{tabular}

All of those aspects improved the students' oral interaction. The category Oral interaction is best achieved along with classmates including the following subcategories: well-disposed behavior and oral proficiency.

\section{Well-disposed behavior}

well-disposed behavior helped the ninth graders to get well along with classmates. It was a constructive learning process into classroom. It involved not to give up, be certain of their abilities, showing self-esteem and self-confidence, among others. Throughout the next extracts, the reader will be presented with the students' voices regarding this subcategory (Table 6). 
Table 6. Extracts.

\begin{tabular}{|c|c|c|}
\hline Extracts from workshops & Extracts from Diary & $\begin{array}{l}\text { Extracts from } \\
\text { interviews }\end{array}$ \\
\hline $\begin{array}{l}\text {-"The students' reactions and their attitudes were } \\
\text { positive concerning the development of this first } \\
\text { workshop; they showed too comfortable working } \\
\text { in this cooperative way. The environment, which } \\
\text { they worked, was an enjoyable tool for them to } \\
\text { achieve the goal; the final presentations showed } \\
\text { the cooperation among them to work, especially } \\
\text { their wishes to help each other to do their best } \\
\text { about the target activity". (I Workshop research } \\
\text { cycle, pag. 39). }\end{array}$ & $\begin{array}{l}\text { - "los estudiantes se sintieron } \\
\text { motivados, porque era una forma } \\
\text { nueva para ellos de salir de lo } \\
\text { rutinario de las clases. Ellos } \\
\text { manifestaron su agrado por el } \\
\text { taller, lo cual nos dio a entender } \\
\text { que los estudiantes les gusta } \\
\text { trabajar siempre y cuando haya } \\
\text { algo novedoso para hacer en aras } \\
\text { del aprendizaje". } \\
\text { (Diario 01, pág.39). }\end{array}$ & $\begin{array}{l}\text {-Me sentí muy cómoda pues } \\
\text { porque era trabajando } \\
\text { con mis compañeros de } \\
\text { salón... (Entrevista 01, } \\
\left.\text { Diana. } 2^{\prime \prime}\right) .\end{array}$ \\
\hline
\end{tabular}

The students agreed that by means of the development of the cooperative learning workshops, they could share their ideas and learn more from one another. The next table (Table 7) shows that the students also said that they had good relationships among themselves, but now those relationships were better than before throughout the implementation of the teams into the English classroom.

Table 7. Extracts.

\begin{tabular}{|c|c|c|}
\hline Extracts from workshops & Extracts from Diary & $\begin{array}{c}\text { Extracts from } \\
\text { interviews }\end{array}$ \\
\hline $\begin{array}{l}\text { - "...those aspects allowed a good development of the } \\
\text { workshop; the students were involved into the activities } \\
\text { completely; and they liked to participate and help each other } \\
\text { to achieve the goal". } \\
\text { - "The majority of the students got well along their classmates } \\
\text { and they continue showing positive attitudes for the } \\
\text { workshops. Students liked to work by teams..." (II Workshop } \\
\text { research cycle, pag. 47). } \\
\text { - "we proposed to take a break for them, but it was not } \\
\text { necessary because students expressed they did not need it, } \\
\text { because they were getting well with the activity they were } \\
\text { doing". (III Workshop research cycle, pag. 49). }\end{array}$ & $\begin{array}{l}\text { - “Los estudiantes están } \\
\text { animados y tienen buena } \\
\text { disposición. Se observa } \\
\text { aire de interés por la clase } \\
\text { de inglés...". (Diario 02, } \\
\text { pág.46). }\end{array}$ & $\begin{array}{l}\text { - pues trabajar en grupos } \\
\text { cooperativos es útil para } \\
\text { nuestro desempeño en } \\
\text { inglés. (Entrevista 03, } \\
\text { Natalia. } 37^{\prime \prime)} \text {. }\end{array}$ \\
\hline
\end{tabular}

According to Biehler and Snowman (1993, p. 48) "if you do not understand how something relates to your goals, you will not care about that thing". In accordance with next table (Table 8), some of the students explained that they felt comfortable in the English classroom and they really enjoyed being in that English class. 
Table 8. Extracts

\begin{tabular}{|c|c|c|}
\hline Extracts from workshops & Extracts from Diary & Extracts from interviews \\
\hline $\begin{array}{l}\text { - "This workshop was developed with } \\
\text { the same students' positive attitude. } \\
\text { Since the beginning, they were } \\
\text { expectants for this session, they } \\
\text { were in constant movement because } \\
\text { they did not have the first classes. } \\
\text { The students did their best helping } \\
\text { each other to carry out the English } \\
\text { activities". (IV Workshop research } \\
\text { cycle, pag. 56). }\end{array}$ & $\begin{array}{l}\text { - “Los estudiantes estuvieron } \\
\text { comprometidos y motivados en la } \\
\text { realización de este último taller, } \\
\text { ya que entendieron a cabalidad la } \\
\text { actividad y cada equipo asimiló el } \\
\text { trabajo cooperativo como una forma de } \\
\text { aprender juntos interactuando con los } \\
\text { otros miembros del equipo”. (Diario 05, } \\
\text { pág. } 67 \text { ). }\end{array}$ & $\begin{array}{l}\text { - "pues que todos tenemos que } \\
\text { cooperar, porque con el trabajo en } \\
\text { grupo si uno no sabe el compañero } \\
\text { le puede aportar mucho a uno, } \\
\text { entonces es como cooperativo, si } \\
\text { uno no sabe le enseña el compañero } \\
\text { y si el compañero no sabe uno le } \\
\text { enseña al compañero. (Entrevista } \\
\text { 01, Diana. 37"). }\end{array}$ \\
\hline
\end{tabular}

As it has been seen throughout the examples, all of their contributions pointed out the fact that they really felt motivated with the experience based on cooperative learning approach. We can see in Table $\mathbf{9}$ that the students got the real meaning about what cooperative learning is. It goes beyond the achievement of a learning task; it is the way of cooperating among each other taking into account the other's opinions to grow as a whole.

Table 9. Extracts.

\begin{tabular}{|c|c|c|}
\hline Extracts from workshops & Extracts from Diary & Extracts from interviews \\
\hline $\begin{array}{l}\text { - "The students were able to analyze and } \\
\text { comprehend a given situation and they } \\
\text { suggested probable resolutions for those } \\
\text { problems according to the situation". } \\
\text { - "The students tried to recognize themselves } \\
\text { as humans and how they could help to solve } \\
\text { others' problems. Some of them expressed } \\
\text { that we could change the world with our } \\
\text { (small) actions if we realize which the role in } \\
\text { our lives is". } \\
\text { - "They also spoke about tolerance and how } \\
\text { they could get along well with others". (III } \\
\text { Workshop research cycle, pag.55). }\end{array}$ & $\begin{array}{l}\text { - “... se resaltó la importancia del } \\
\text { aprendizaje cooperativo y cómo } \\
\text { estos talleres no sólo les había } \\
\text { permitido aprender inglés, sino } \\
\text { mejorar como seres humanos, } \\
\text { enriqueciendo valores como el } \\
\text { respeto, solidaridad, amistad, } \\
\text { tolerancia, entre otros". } \\
\text { - “...los equipos habían entendido las } \\
\text { actividades debido a su actitud y } \\
\text { su disposición de hacer las cosas } \\
\text { y llegar a un fin cooperativo donde } \\
\text { todos aprendíamos de todos". } \\
\text { (Diario 04, pág. 60). }\end{array}$ & $\begin{array}{l}\text { - en el trabajo en grupo podemos } \\
\text { intercambiar ideas y podemos } \\
\text { también, saber lo que los demás } \\
\text { piensan y ayudarnos unos a } \\
\text { otros para el emprendimiento } \\
\text { para el mañana (Entrevista 02, } \\
\text { Felipe. } 22 ") \text {. }\end{array}$ \\
\hline
\end{tabular}

Through the development of this investigation, ninth graders expressed to have a welldisposed behavior in the development of the cooperative learning workshops, since they had not had an experience like this as English learners in previous levels. They found that those workshops were relevant for them, because workshops could help them to gain not just well-disposed behavior but confidence and motivation to put into practice the English oral interaction. In addition, they assumed that working in teams was a way to overcome fear and learn together.

Therefore, the workshops and teacher's diary evidenced the relevance of working in teams since it characterizes their interest towards cooperative learning approach. In this way, 
the students demonstrated their interest to be in charge of their performance in positive ways. As Biehler and Snowman (1993, p. 49) explained before "we do not want our children to be motivated solely by a desire to please the teacher, what we need to address is how to make the content of the curriculum fit into the concerns of the child". Similarly, what the students expressed in the interviews showed that they agreed in having a welldisposed behavior for the activities planned for the investigation, which in essence involved cooperative learning approach.

\section{Oral proficiency}

Based on my experience as a teacher-researcher and taking into account my continuous observation, at the beginning it was difficult to encourage ninth graders to speak in English. However, as we can see in Table 10, cooperative learning approach played an important role as a tool to reduce the students' oral interaction difficulties, because It allowed them to be cooperative and they could do their best to learn vocabulary, pronunciation, sentence structure in order to interact orally with each other.

Table 10. Extracts.

\begin{tabular}{|c|c|c|}
\hline Extracts from workshops & Extracts from Diary & $\begin{array}{l}\text { Extracts from } \\
\text { interviews }\end{array}$ \\
\hline $\begin{array}{l}\text { - "The students were asked about some idiomatic } \\
\text { expressions in order to use them in their speeches. It was } \\
\text { very useful for the students' oral interaction. Therefore, the } \\
\text { students' teams organized themselves as a "panel" and } \\
\text { they started to participate following an order. One member } \\
\text { asked to another and so on. After that, the students } \\
\text { answered some questions according to the other teams } \\
\text { were listened to". } \\
\text { - "it allowed the students to interact orally among them } \\
\text { inside the team". (III Workshop research cycle, pag.50). } \\
\text { - "the students took pictures and prepared a presentation } \\
\text { with four descriptions of school places by team. The } \\
\text { students looked for unknown vocabulary to express their } \\
\text { speeches about places and with the help of the teacher and } \\
\text { themselves, they practiced the pronunciation team by team. } \\
\text { Afterwards, the team made the presentation with video- } \\
\text { beam and answered some questions from the other teams". } \\
\text { - "...showed the students were able to use lot of English. } \\
\text { All the time, the students tried to speak English inside the } \\
\text { team to make explanations; they made the descriptions' } \\
\text { presentations and answered the questions according to } \\
\text { the place they were speaking about. It means, the English } \\
\text { language used by ninth graders indicated that they were } \\
\text { making their best effort to express their ideas concerning } \\
\text { to the topic and achieving the goal". (IV Workshop research } \\
\text { cycle, pag. 61). }\end{array}$ & $\begin{array}{l}\text { - “...los estudiantes hablaron } \\
\text { de sus héroes favoritos de } \\
\text { las películas, los programas } \\
\text { de televisión y las revistas } \\
\text { de tiras cómicas, y ellos } \\
\text { hablaron de los super-héroes } \\
\text { que ya habíamos reseñado } \\
\text { en el taller anterior porque ya } \\
\text { tenían un vocabulario básico al } \\
\text { respecto". (Diario 03, pág. 53). }\end{array}$ & $\begin{array}{l}\text { - ...muy contenta, porque } \\
\text { el inglés es algo que } \\
\text { nos va a servir para la } \\
\text { vida y es interesante } \\
\text { verlo en el colegio como } \\
\text { el profesor nos enseñó, } \\
\text { en grupos porque } \\
\text { uno podía hablar con } \\
\text { los compañeros sin } \\
\text { miedo...". (Entrevista } \\
\left.02, \text { Natalia. } 29^{\prime \prime}\right) \text {. }\end{array}$ \\
\hline
\end{tabular}

The students felt that cooperative learning approach helped their English oral proficiency. It means, most of the students were able to express orally inside the team and in front of their classmates. Due to this, the students could discuss and solve the task assigned to the teams. The Table 11 shows that students were aware of the discussing topics, contributing with solutions and developing the activities among the members of the team with the possibility to help and be helped when having difficulties. 
Table 11. Extracts.

\begin{tabular}{|c|c|c|}
\hline Extracts from workshops & Extracts from Diary & $\begin{array}{c}\text { Extracts from } \\
\text { interviews }\end{array}$ \\
\hline $\begin{array}{l}\text { - "...the students were able to act out, talk about heroes, } \\
\text { describe and compare them using comparative and } \\
\text { superlative adjectives". (II Workshop research cycle, pag. 47). } \\
\text { - "...every team had to answer the teacher questions. However, } \\
\text { they had to prepare the answer into the team helping each } \\
\text { other. An example of a teacher question: What is the cause } \\
\text { of the origin of those conflicts? and, what would be a } \\
\text { solution to those conflicts? At random, The teacher chose a } \\
\text { student by team, to socialize the answers". } \\
\text { - “...the students interact orally, interchanging information } \\
\text { about their cities". } \\
\text { - "...the students were able to use English language as a } \\
\text { way of expressing the information they found about their } \\
\text { topics, also, it allowed to express opinions about the events } \\
\text { that happened in those cities. They expressed what they } \\
\text { wanted to say according to the information. They interacted } \\
\text { in English through basic vocabulary and expressions, so, } \\
\text { the English language was according to the activities". (V } \\
\text { Workshop research cycle, pag. 68). }\end{array}$ & $\begin{array}{l}\text { - “...los equipos socializaron } \\
\text { sus descripciones, con } \\
\text { fotografías y video beam, } \\
\text { en frente de cada grupo. } \\
\text { Inicialmente, los estudiantes } \\
\text { hablaron en equipo del lugar } \\
\text { y, luego, individualmente, } \\
\text { hablaron de cómo les gustaría } \\
\text { vestirse para venir al colegio. } \\
\text { Finalmente, también en } \\
\text { equipo, y usando los mismos } \\
\text { recursos tecnológicos, los } \\
\text { estudiantes describieron la } \\
\text { imagen tomada de la revista } \\
\text { de televisión. Para cerrar, los } \\
\text { estudiantes respondieron } \\
\text { unas preguntas en relación } \\
\text { con cómo les pareció la } \\
\text { actividad y cómo se sintieron } \\
\text { trabajando en equipo". (Diario } \\
\text { 01, pág.39). }\end{array}$ & $\begin{array}{l}\text {...bien porque podemos } \\
\text { intercambiar ideas y } \\
\text { ponernos de acuerdo } \\
\text { para hacer lo que } \\
\text { teníamos que hacer. Y } \\
\text { podemos también, pues } \\
\text { decir lo que habíamos } \\
\text { preparado con los otros } \\
\text { en el grupo... (Entrevista } \\
\left.\text { 02, Felipe. } 49^{\prime \prime}\right) \text {. }\end{array}$ \\
\hline
\end{tabular}

Throughout the information provided by students regarding to this subcategory, it showed that the implementation of cooperative learning approach characterized their oral interaction, of course the English skills as well, to cooperate among them. That is, when a student knew how to write, read or pronounce something he had the responsibility to tell the others; in that way, through cooperation the planned topic to be developed during the class was almost covered because of the ninth graders' contributions. Besides, it is necessary to say that the students knew some vocabulary previously, and they use it to rehearse their oral interaction to cooperate among them.

Furthermore, it showed that the students who worked together could improve their academic level. It can be seen also as an indicator that shows how much the students learnt and the degree of performance in the English language. It means that cooperative learning approach made students get better levels of achievement. In fact, the cooperative learning approach helped the ninth graders to improve their English oral interaction; since among other reasons, the difficulties were for them better solved by teams than individually. Interpretation.

In summary, I must say that I wrote a diary where I noticed different aspects such the development of the research study workshop by workshop. Those observations can give account of the whole process that I carried out with this cooperative learning approach. The social relations among the students are evidenced in the diary, because there was more acceptation among them, which allowed to work by teams cooperatively.

According to interviews and informal dialogues, the students felt comfortable when they used the English language, many times they used switching. It means some ninth graders used Spanish words 
to express their points of view. The students got familiar with switching, since it was a useful and easy way to put into practice the English language. Currently, I consider that switching is a suitable mean to diminish the fair's student and to facilitate speaking.

In every workshop, I provided the students with information aboutthe given themeand topic, then I suggested them to look for more information by themselves. It was relevant because the students were capable to complement what they received in class. The students tried to use the most familiar vocabulary related to all these topics. At the end, the students became aware of their need to speak in English.

Here, it is important to mention that in a competitive work, participants inside a group perform as individuals. For instance, when a member of a team fails, it is actually an opportunity for the rest of the students to gain a score. This idea is too far from what cooperative learning means as I have said before.

Consequently, oral interaction was enhanced because all members of the teams had the chance to hear and be heard by their classmates. Although, the speaking skill is crucial in a cooperative learning classroom environment, since it allows the students to use the language in real and meaningful situations, the development of the four English skills were worked as a whole. For this particular study, speaking was developed more than the other skills, because it is close related with the development of the oral English interaction.

The students revealed most interest towards the development of the speaking skill, when they were allowed to discuss about a topic as a team. They asked always for more time to discuss their concerns. At the end, all the groups did their presentations. Every member of each team made their contributions, it did not matter if someone participated more than the others did.

As a final point, the data gathered by means of the instruments, indicated that through the cooperative learning approach is possible to observe the development of students' oral interaction and, consequently, its improvement. Besides, through the cooperative learning approach, the ninth graders were aware of their needs, strengths and weaknesses as learners. In addition, the data suggests that the students were able to improved their English oral interaction, through cooperative learning approach and, at the same time, understand what team group means. Furthermore, the cooperative learning approach improved social relations, since ninth graders were used to work alone and into the classrooms is common the existence of a group of students who are more advanced than the rest of the whole group. In this case, it was an opportunity for the less advanced students to be part of a group; consequently, social relations were improved.

\section{Conclusions}

Learners were aware of the importance of the English oral interaction. The students solved many academic difficulties they had at the beginning of the study. Doubts related to vocabulary, sentence structure, pronunciation, word order, miswritten words and, in general, with formal rules of language were worked and clarified through cooperation among teammates inside the team. 
As in all teaching-learning experiences, weaknesses also make important part, since it is not common to find everything perfect. In this research experience, the teacher-researcher could find as a weakness the fragility of students to forget learned habits. We believe that cooperative learning approach should be promoted constantly in order for students and teachers to be committed with this concern. It would be suitable to accomplish an interdisciplinary work in which all the subjects should be included. Cooperative learning is not just appropriated for students but also for teachers to improve our pedagogical practices and allow us to be more reflective and critical about our role.

Along the research study development, it concluded that implementation of cooperative learning approach improved oral interaction in ninth graders, because ninth graders had brought positive outcomes to the students' English learning process. Teamwork rose their interest to interact orally each other, it means, students felt motivated and interested in practicing English. In this way, the concept of the English language subject was not a boring idea and they enjoyed doing better their oral interaction.

\section{References}

- Biehler, R. \& Snowman, J. (1993). Psychology applied to teaching. Boston: Houghton Mifflin Company.

- Brandt, F. J. \& Ellsworth, N. J. (1996). Effects of cooperative learning on the academic achievement and self-steem of urban adolescents with learning disabilities. Learning Disabilities 7, 9-73.

- Calderón-Noguera, D. F. (2011). El papel de la entrevista en la investigación sociolingüística. Cuadernos de lingüística hispánica. N 17. Tunja. Uptc. Recovered from https://revistas.uptc.edu. co/revistas/index.php/linguistica_hispanica/ article/view/423/423
- Casteblanco-Cifuentes, C. L. (2015). El taller literario un espacio para promover la escritura. Prospectiva Científica. № 11. Pag. 279-290. Tunja. Uptc. Recovered from https://www.academia. edu/19660889/El_taller_literario_un_espacio_ para_promover_la_escritura

- Cohen, E. G. (1972). Designing groupwork: Strategies for the heterogeneous Classroom. New York. Teachers College Press.

- Coleman, J. S. (1961). The Adolescent Society. New York: Free Press of Glencoe. Cooper, G. L. (1979). Learning from others in groups-Experiential learning approaches. London, Associated business press.

- Cooper, G. L. (1979) Learning from others in groups - Experiential learning. Approaches. London, Associated Business Press.

- Firestone, W. (1987). Meaning in method. The rhetoric of quantitative and qualitative research. Educational researcher.

- Hamm, M. \& Adams, D. (1992). The collaborative dimensions of learning. Norwood, NJ. Ablex Publishing Company

- Holt, D., Chips, B. \& Wallace, D. (1991). "Cooperative learning in the secondary school: Maximizing language acquisition, academic achievement, and social development". National Clearinghouse for Bilingual Education Program Information Guide Series. Number 12, Summer.

- Johnson, D. W., \& Johnson, R. T. (1989). Cooperation and competition: Theory and research. Edina, MN. Interaction Book Company.

- Johnson, D. W. \& Johnson R. T. (1995). Learning together and alone. $3^{\text {rd }}$ edition. Englewood Cliffs, New Jersey: Prentice Hall.

- Kagan, S. (1994). Cooperative Learning. San Clement, CA. Kagan Publishing. Recovered from http://www.kaganonline.com

- Kemmis, S. \& McTaggart, R. (2000). Participatory action research. In N. Denzin, \& Y. Lincoln (Eds.). Handbook of qualitative research $\left(2^{\text {nd }}\right.$ ed. Pp. 567505). Thousand Oaks, CA. Sage. 
- McGroarty, M. (1993). Cooperative Learning and second language acquisition. In D. Holt, Cooperative learning. Washington, DC. Center for Applied Linguistics and ERIC Clearing house on Languages and Linguistics.

- Mills, G. E. (2003). Action research: A guide for the teacher researcher. Upper Saddle River, NJ. Merrill/Prentice Hall.

- Oxford, R. L. (1997). Cooperative Learning, Collaborative Learning, and Interaction: Three Communicative Strands in the Language Classroom Education. Alabama. University of Alabama.
- Parsons, R. \& Brown, K. (2002). Teacher as reflective practitioner and action researcher. Belmont, CA: Wadsworth /Thomson Learning.

- Porlán, R. \& Martín, J. (2000). El diario del profesor, Un recurso para la investigación en el aula. Recovered from https://profesorailianartiles.files. wordpress.com/2013/03/diario-del-maestro.pdf

- Slavin, R. (1995). Cooperative learning. Boston: Allyn and Bacon. (1964). Using Student Team Learning. 4th ed. Baltimore: Johns Hopkin University, Center for Social Organization of Schools. 